\title{
THE ROLE OF PHILOSOPHY AND LANGUAGE IN THE DIALOGUE CULTURAL
}

Sally Abdel Hafiz, Muhammad ABDEL HAFIZ *

Faculty of Education, Helwan University, Egypt

\begin{abstract}
There is an overlook of the role of philosophy and language in the cultural dialogue due to the weakness of the philosophical dialogue in our country instead talking about his absence and lack of interest in language well and knowing its correct rules and foundations. Philosophical activity to us, it is non-existent that it is present in education, in programs of publishing houses, and in the activities of cultural institutions. There is a great discrepancy between Arab countries in their care, and it is regrettable that there is no comprehensive and objective picture of it that helps.

Keywords

Philosophy, Language, Dialogue, Cultural.
\end{abstract}

\section{Introduction}

To deal with it, and in fact, there is a common reductionist tendency to say that there is no existence of contemporary Arab philosophy.

This tendency has reasons, goals, and consequences. If it is true that there is no contemporary Arab philosophy, then the issue of philosophical dialogue they become without an objective basis, because we find that those who feel the necessity of philosophy in our countries do not do much to promote it and revitalize them and spread their influence in society. This is reflected negatively on the level of cultural dialogue among societies.

Cultural dialogue includes taking and responding, on understanding and criticism, on sharing, understanding, and asking for a stronger argument.

Regarding a specific problem, in itself, in its causes and in its consequences, the role of philosophy in cultural dialogue must be strengthened.

The issue is not a matter of quantity (the increase in the number of literature on philosophical affairs, the emergence of philosophical journals, the formation of philosophical societies, holding philosophical (rather qualitative) seminars. How does the author present the problem, how does he justify its presentation, and how does he deal with it?

Its history? What is the degree of his conviction with the content of his research for her? etc....). This means that the influence of ethical psychological factors is an image Negative attitudes towards cultural dialogue should be appreciated in light of the low quality of philosophical commitment and research.

Philosophy explains who is talking to us? What is the topic of the dialogue: Is the current

* Corresponding author: info@edu.helwan.edu.eg 
dialogue really different from the debate?

And about the debate? How is criticism used with dialogue? What are the reasons and the stated and implicit goals of the dialogue? Etc ...,

Most of the philosophical debates taking place in all regions of the Arab world for three decades.

Hence, we find that we are faced with two types of "philosophical" speakers:

The first type: is the one who knows the truth about things that others do not know about which he discusses in good faith according to the requirements of the dialogue and who Without realizing it from the ignorance of his listeners, which is what the philosophers forbade him by saying: "Do not talk about philosophy in front of people who are not philosophical.

The second type: he is a philosophy prosecutor who speaks everything without diving deep and does not come out with a result this type. He collects fragments of knowledge that he heard or read from here and there; trying to reflect them in the mirror of philosophy, thinking that he is polishing his image and his cultural views. And in our Arab societies, the spread of the second type prevails over the first, and because of this, the public began to give their judgments on this segment of people, they began to describe them as philosophers.

\section{Accordingly, this work has been divided into two parts:}

The first: the role of philosophy in cultural dialogue Philosophy is a tool for cultural dialogue Methodology for cultural dialogue

Cultural heritage and its philosophical tributaries the phenomenon of influence and influence.

The second: the role of language in cultural dialogue, The importance of language in intercultural dialogue Martin Heidegger's conception of language.

\section{The Arabic language and its role in cultural dialogue}

I will use the analytical method to analyze the ideas contained in this work that support the role of both philosophy and language in cultural dialogue.

\section{First: the role of philosophy in cultural dialogue}

Philosophy is a tool for cultural dialogue:

Philosophy, as it is a resistance that works against everything that would perpetuate congruence, harmony, and harmony

Tradition is an assertion that every supposed understanding conceals an original misunderstanding. As such, the philosophical dialogue does not. It aims to achieve the minimum level of understanding. On the contrary, it aims to show that what is presented as points convergence may be points of separation, and what is considered an understanding may entail misunderstanding. However, it is not necessarily a misunderstanding between The 
interlocutors, but it may be mainly a misunderstanding of the thought with itself, a misunderstanding of self.

\section{Second: The role of language in cultural dialogue}

The importance of language in intercultural dialogue:

Language is one of the builders of human ideas, and it is what distinguishes it from other animals, through it the individual is aware of his words .Unlike other animals, despite having speech organs. They are considered two sides of the same coin, which are closely related and cannot be separated, and the evidence for this is that We think through language.

Language - as determined by most of its scholars - its function is not limited to interpersonal understanding, but rather goes beyond that to the tool by which a person learns and thinks, as it leads and directs his mind, and with it he inferred good behavior with others, namely -In addition to that - preserving the cultural heritage of societies; It is therefore the organizer of social relations and the medium of interaction And cooperation between members of society is the most important tool for preserving its existence, and it follows that it is the first factor in the spread of culture .And its circulation in civilized societies, and that it is one of the most important components of human civilization and upon which high cultural dialogue is based Civilized.

\section{The Arabic language and its role in cultural dialogue}

The Arabic language was - and is - closely linked to the identity, existence and character of this nation.And its characteristics, since long ago it became aware of the cultural formation of the nation, and accompanied the development of its cultural heritage in science and literature. Arts, legislation and philosophy, and has pledged to transmit it from generation to generation through the ages, as it is the beating heart of the nation and its apparatus.

The engine and it is known that Arabic is one of the ancient languages, so despite our ignorance of the details of its inception, because the first ones did not leave traces written from immemorial times, we know that it was at its height and maturity some sixteen centuries ago, The dialects of the Arab tribes on the island interacted with one another and complemented them in the dialect of Quraysh, the people of Mecca, which was a center of economic, social and religious life taken in by tribes to visit the Holy Kaaba, to boast and compete in poetry. And rhetoric, and for trade and exchange of goods.

\section{References}

Martin Heidegger: Being and Time, translated by Fathi Al-Maskini, Review of Ismail AlMosadq, Dar Al-Kitab Al-Jadid, First Edition, Beirut, 2012

- Martin Heidegger, Basic Writings C2, First Edition, Cairo, 2003, p. 261, translated by Ismail 
Al-Mossadegh, Supreme Council of Culture

- Ben Abdelali Abdel Salam: Philosophy is a Tool for Dialogue, Dar Toubkal Casablanca, First Edition, 2011

-. Jaber Asfour: Human and Creative Diversity, Report of the International Committee for Culture and Development, the Supreme Council for Culture. The National Project for Translation (27), Cairo, 1997

- Hassib Shehadeh: The Role of Language in Culture, Civilized Dialogue, No. 1853

- Zaki Naguib Mahmoud: The Story of Greek Philosophy, Second Edition, Egyptian Book House, Cairo, 1935

-. Sateh Al Hosary: What Nationalism, Dar Al Alam for Millions, Beirut, 1959

-. Salih Abu Asba, Ezz Al-Din Manasra, Muhammad Ubayd Allah: Dialogue with the Self, Papers of the Eighth International Conference. College of Letters and Arts, University of Philadelphia, 2003

-. Abdullah Al-Tatawi: Cultural Dialogue, Communication and Belonging Project, The Egyptian Lebanese House, First Edition 2006,

-. Fatima Lotfi Koudarzi: The Impact of the Arabic Language on Islamic Culture, Literary and Linguistic Aluka Network, 5/10/2010.

-. Kamal Sayed Hassan: The Problem of Dialogue and the Clash between Civilizations, (DT), Egypt, 2006

-. Muhammad Mahmoud Abd Al-Hamid Abu Qahf: The Alexandria School of Philosophy "Civilized History and Cultural Dialogue". Dar Al-Wafa Printing and Publishing, First Edition, 2004

-. Najib Baladi: Introduction to the History of the Alexandria School, Dar Al Maaref, Cairo, 1962

- Muna ARAFA, Farida BADR, THE EFFECTIVENESS OF A PROPOSED ARAB CULTURE APPROACH FOR THE SPEAKERS OF OTHER LANGUAGES TO LEARNING THE ARABIC LANGUAGE, International Journal of Humanities and Language Research, Vol. 3, No. 1, 2020, pp. 1-14. 